\begin{tabular}{|c|c|}
\hline $\begin{array}{l}\text { Chemistry of } \\
\text { Metals and Allovs }\end{array}$ & 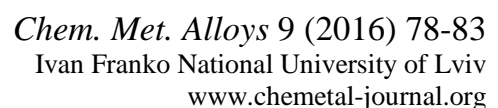 \\
\hline
\end{tabular}

\title{
Crystal structure of the ternary compound $\mathrm{Sc}_{3} \mathrm{Cu}_{7.5} \mathrm{Al}_{7.5}$
}

\author{
Nastasia KLYMENTIY ${ }^{1 *}$, Nataliya SEMUSO ${ }^{1}$, Svitlana PUKAS ${ }^{1}$, Yaroslav TOKAYCHUK ${ }^{1}$, Lev AKSELRUD ${ }^{1}$, \\ Roman GLADYSHEVSKII ${ }^{1}$ \\ ${ }^{1}$ Department of Inorganic Chemistry, Ivan Franko National University of Lviv, \\ Kyryla i Mefodiya St. 6, 79005 Lviv, Ukraine \\ * Corresponding author.Tel.: +380-32-2394506; e-mail: klymentiynastasia@gmail.com
}

Received May 28, 2016; accepted June 19, 2016; available on-line November 7, 2016

The crystal structure of a new ternary aluminide, $\mathrm{Sc}_{3} \mathrm{Cu}_{7.5} \mathrm{Al}_{7.5}$, was solved by direct methods from $\mathrm{X}$-ray powder diffraction data. It crystallizes with a partly disordered occupation variant of the structure type $\mathrm{Sc}_{3} \mathrm{Ni}_{11} \mathrm{Ge}_{4}$ (Pearson symbol $h P 38$, space group $P 6_{3} / m m c, a=8.4848(1), c=8.8593(1) \AA$ ). The hexagonal unit cell of $\mathrm{Sc}_{3} \mathrm{Cu}_{7.5} \mathrm{Al}_{7.5}$ contains 36 atoms, distributed over seven crystallographic sites (Sc atoms: one site, statistical mixtures of $\mathrm{Cu}$ and $\mathrm{Al}$ atoms: four sites, $\mathrm{Cu}$ atoms alone: two partly occupied sites). The main feature of the structure is the clustering of the Sc atoms into triangles with relatively short interatomic distances $\left(\delta_{\mathrm{Sc}-\mathrm{Sc}}=3.446(2) \AA\right)$. The coordination polyhedra of the Sc atoms are pentagonal prisms (with seven capping atoms) and those of the sites occupied by atoms of the statistical mixtures icosahedra, and those of the remaining $\mathrm{Cu}$ atoms trigonal prisms (with three capping atoms) or trigonal antiprisms.

Aluminum / Copper / Scandium / X-ray powder diffraction / Crystal structure / Rare-earth atom triangles

\section{Introduction}

Data available on the $\mathrm{Sc}-\mathrm{Cu}-\mathrm{Al}$ system and other $R-\mathrm{Cu}-\mathrm{Al}$ systems were reviewed in [1]. The interaction of the components in the $\mathrm{Sc}-\mathrm{Cu}-\mathrm{Al}$ system at $500^{\circ} \mathrm{C}$ has been investigated in the concentration range 0-33.3 at.\% Sc [2]. The existence of two previously reported compounds: $\mathrm{ScCu}_{2} \mathrm{Al}$ (structure type $\mathrm{CsCl}$, Pearson symbol $c P 2$, space group $P m-3 m$ ) and $\mathrm{ScCuAl}\left(\mathrm{MgZn}_{2}, h P 12, P 6_{3} / m m c\right)$ [3], was confirmed, the formation of seven new ternary intermetallics was established, and the partial isothermal section of the phase diagram was constructed. The crystal structure of the extended solid solution $\mathrm{ScCu}_{4-6.6} \mathrm{Al}_{8-5.4}$ was identified as belonging to the structure type $\operatorname{ThMn}_{12}(t I 26, I 4 / \mathrm{mmm})$. For the intermetallide assigned the approximate composition $\mathrm{ScCu}_{2} \mathrm{Al}_{2}$ (A), orthorhombic cell parameters were determined, whereas for the remaining five compounds, $\mathrm{ScCu}_{4} \mathrm{Al}_{3}$ (E), $\mathrm{Sc}_{3} \mathrm{Cu}_{13} \mathrm{Al}_{4}$ (D), $\mathrm{ScCu}_{3} \mathrm{Al}_{2}$ (B), $\mathrm{Sc}_{3} \mathrm{Cu}_{8} \mathrm{Al}_{7}(\mathrm{C})$, and $\mathrm{ScCu}_{1.4} \mathrm{Al}_{0.6}(\mathrm{~F})$, only approximate compositions were established. Independent studies of the Al-rich part of the system [4-6] led to slightly different conclusions concerning the tie-lines in this part of the system, both at 450 and $500^{\circ} \mathrm{C}$. The authors also studied a few polythermal sections and the corresponding part of the solidus projection.

Later on, the compositions of the compounds $\sim \mathrm{Sc}_{3} \mathrm{Cu}_{13} \mathrm{Al}_{4}, \quad \sim \mathrm{ScCu}_{3} \mathrm{Al}_{2}$, and $\sim \mathrm{Sc}_{3} \mathrm{Cu}_{8} \mathrm{Al}_{7}$ were refined to $\mathrm{Sc}_{2} \mathrm{Cu}_{7.5} \mathrm{Al}_{3.5}, \quad \mathrm{Sc}_{6} \mathrm{Cu}_{16.4} \mathrm{Al}_{13.9}$, and $\mathrm{Sc}_{3} \mathrm{Cu}_{9} \mathrm{Al}_{7}$, respectively, and cell parameters were determined $[7,8]$. The crystal structure of a new compound, $\mathrm{ScCu}_{0.6} \mathrm{Al}_{1.4}$, was found to belong to the hexagonal $\mathrm{MgNi}_{2}$ type $\left(h P 24, P 6_{3} / m m c\right)$ [7-9]. The crystal structure of the compound $\mathrm{ScCu}_{2} \mathrm{Al}$ was redetermined based on $\mathrm{X}$-ray single-crystal diffraction and the cubic $\mathrm{MnCu}_{2} \mathrm{Al}$ type ( $c F 16$, $F m-3 m$ ), assigned in [10], was confirmed [7-9], whereas the $\mathrm{CsCl}$ type $(c P 2, P m-3 m)$ reported in [3] may correspond to a stabilized modification of the same compound.

Two more compounds, with own structure types, form in the system $\mathrm{Sc}-\mathrm{Cu}-\mathrm{Al}: \mathrm{Sc}_{2} \mathrm{Cu}_{6.25} \mathrm{Al}_{4.75}$ (oS108, Cmmm) and $\mathrm{Sc}_{6} \mathrm{Cu}_{24.1} \mathrm{Al}_{11.9}(c I 176$, Im-3) [11,12]. The starting model for the crystal structure of the compound $\mathrm{Sc}_{2} \mathrm{Cu}_{6.25} \mathrm{Al}_{4.75}$ was constructed theoretically using the so-called 'cell constrained melt-quenching technique' [11]. The crystal structure of $\mathrm{Sc}_{6} \mathrm{Cu}_{24.1} \mathrm{Al}_{11.9}$ was solved by direct methods from $\mathrm{X}$-ray powder diffraction data and may be described as a packing of 16-vertex coordination polyhedra of the Sc atoms, which form icosahedral clusters around the origin and the center of the body-centered unit cell [12]. The voids at the centers of the clusters are filled by $\mathrm{Cu}_{4}$ empty tetrahedra, disordered between two possible orientations. The crystallographic parameters of compounds reported in the $\mathrm{Sc}-\mathrm{Cu}-\mathrm{Al}$ system are listed in Table 1. 


\section{Experimental}

An alloy of nominal composition $\mathrm{Sc}_{20} \mathrm{Cu}_{40} \mathrm{Al}_{40}$ and total mass $1 \mathrm{~g}$ was synthesized from the metals (purity for $\mathrm{Sc} \geq 99.99$ mass\%, $\mathrm{Cu} \geq 99.99$ mass\%, $\mathrm{Al} \geq 99.998$ mass \%) by arc melting, in a water-cooled copper crucible with a tungsten electrode under a purified argon atmosphere (using $\mathrm{Ti}$ as a getter). The ingot was annealed at $600^{\circ} \mathrm{C}$ under vacuum in a quartz ampoule for 1 month, and subsequently quenched in cold water.

Phase and structural analyses were performed using X-ray powder diffraction data collected on a diffractometer STOE Stadi P (Cu $K \alpha_{1}$-radiation) in the angular range $6^{\circ} \leq 2 \theta \leq 107.745^{\circ}$ (step $0.015^{\circ}$, scan time $230 \mathrm{~s}$ per step). The sample was found to contain two ternary intermetallics, $\mathrm{Sc}_{3} \mathrm{Cu}_{7.5} \mathrm{Al}_{7.5}$ and $\mathrm{ScCu}_{0.6} \mathrm{Al}_{1.4}$ (89 and 9 mass\%, respectively), and small amounts of $\mathrm{Sc}_{2} \mathrm{O}_{3} \quad(2 \mathrm{mass} \%)$. The profile and structural parameters were refined by the Rietveld method, using the program DBWS-9708 [13]. After several tests of different models, Wyckoff positions $2 a$ and $2 b$ were found to be partly occupied by $\mathrm{Cu}$ and in the final refinement the sum of their occupancies was constrained to 1 . The structure drawings were made with the program ATOMS [14]. Experimental details of the structural refinement and the crystallographic data of the ternary compound are presented in Table 2.

\section{Results and discussion}

Atomic coordinates and isotropic displacement parameters for $\mathrm{Sc}_{3} \mathrm{Cu}_{7.5} \mathrm{Al}_{7.5}$ are given in Table 3, interatomic distances, coordination numbers, and coordination polyhedra are listed in Table 4. The experimental, calculated and difference $\mathrm{X}$-ray powder diffraction patterns of the sample $\mathrm{Sc}_{20} \mathrm{Cu}_{40} \mathrm{Al}_{40}$ are shown in Fig. 1.

Table 1 Crystallographic parameters of the compounds in the $\mathrm{Sc}-\mathrm{Cu}-\mathrm{Al}$ system.

\begin{tabular}{|c|c|c|c|c|c|c|c|}
\hline Compound & $\begin{array}{c}\text { Structure } \\
\text { type }\end{array}$ & $\begin{array}{c}\text { Pearson } \\
\text { symbol }\end{array}$ & $\begin{array}{l}\text { Space } \\
\text { group }\end{array}$ & $a, \AA$ & $b, \AA$ & $c, \AA$ & Ref. \\
\hline $\mathrm{ScCu}_{4-6.6} \mathrm{Al}_{8-5.4}$ & $\mathrm{ThMn}_{12}$ & $t I 26$ & $I 4 / \mathrm{mmm}$ & $8.66-8.63$ & - & $4.43-5.10$ & {$[3]$} \\
\hline $\mathrm{ScCu}_{4} \mathrm{Al}_{3}$ & $\ldots$ & $\ldots$ & $\ldots$ & $\ldots$ & $\cdots$ & $\ldots$ & {$[2]$} \\
\hline $\mathrm{Sc}_{6} \mathrm{Cu}_{24.1} \mathrm{Al}_{11.9}$ & $\mathrm{Sc}_{6} \mathrm{Cu}_{24.1} \mathrm{Al}_{11.9}$ & $c I 176$ & Im-3 & 13.5337 & - & - & [12] \\
\hline $\mathrm{Sc}_{2} \mathrm{Cu}_{6.25} \mathrm{Al}_{4.75}$ & $\mathrm{Sc}_{2} \mathrm{Cu}_{2}\left(\mathrm{Cu}_{0.47} \mathrm{Al}_{0.53}\right)_{9}$ & $o S 108$ & Cmmm & 8.337 & 22.02 & 8.305 & [11] \\
\hline $\mathrm{Sc}_{2} \mathrm{Cu}_{7.5} \mathrm{Al}_{3.5}$ & $\ldots$ & $h P 24$ & P6/mmm & 4.913 & - & 18.420 & [8] \\
\hline $\mathrm{Sc}_{3} \mathrm{Cu}_{9} \mathrm{Al}_{7}$ & $\ldots$ & $o S 116$ & $\mathrm{Cmmm}$ & 8.355 & 21.977 & 8.319 & [8] \\
\hline $\mathrm{Sc}_{6} \mathrm{Cu}_{16.4} \mathrm{Al}_{13.9}$ & & $h P 44$ & & 8.493 & & 8.870 & [8] \\
\hline $\mathrm{Sc}_{3} \mathrm{Cu}_{7.5} \mathrm{Al}_{7.5}$ & $\mathrm{Sc}_{3} \mathrm{Ni}_{11} \mathrm{Ge}_{4}$ & $h P 38$ & $\mathrm{~Pb}_{3} / m m c$ & $8.4848(1)$ & & $8.8593(1)$ & this work \\
\hline $\mathrm{ScCu}_{2} \mathrm{Al}_{2}$ & $\ldots$ & $o \ldots$ & $\ldots$ & 8.46 & 8.86 & 14.65 & [2] \\
\hline $\mathrm{ScCu}_{2} \mathrm{Al}$ & $\mathrm{MnCu}_{2} \mathrm{Al}$ & $c F 16$ & $F m-3 m$ & 6.2033 & - & - & [9] \\
\hline $\mathrm{Sc}_{0.5} \mathrm{CuAl}_{0.5}$ stab. & $\mathrm{CsCl}$ & $c P 2$ & $P m-3 m$ & 3.10 & - & - & [3] \\
\hline $\mathrm{ScCu}_{0.6} \mathrm{Al}_{1.4}$ & $\mathrm{MgNi}_{2}$ & $h P 24$ & $\mathrm{PG}_{3} / m m c$ & 5.252 & - & 17.113 & [9] \\
\hline $\mathrm{ScCuAl}$ & $\mathrm{MgZn}_{2}$ & $h P 12$ & $\mathrm{PG}_{3} / m m c$ & 5.04 & - & 8.24 & [3] \\
\hline $\mathrm{ScCu}_{1.4} \mathrm{Al}_{0.6}$ & $\ldots$ & $\ldots$ & $\ldots$ & ser & $\ldots$ & & [2] \\
\hline
\end{tabular}

Table 2 Details of the Rietveld refinement of the sample $\mathrm{Sc}_{20} \mathrm{Cu}_{40} \mathrm{Al}_{40}$.

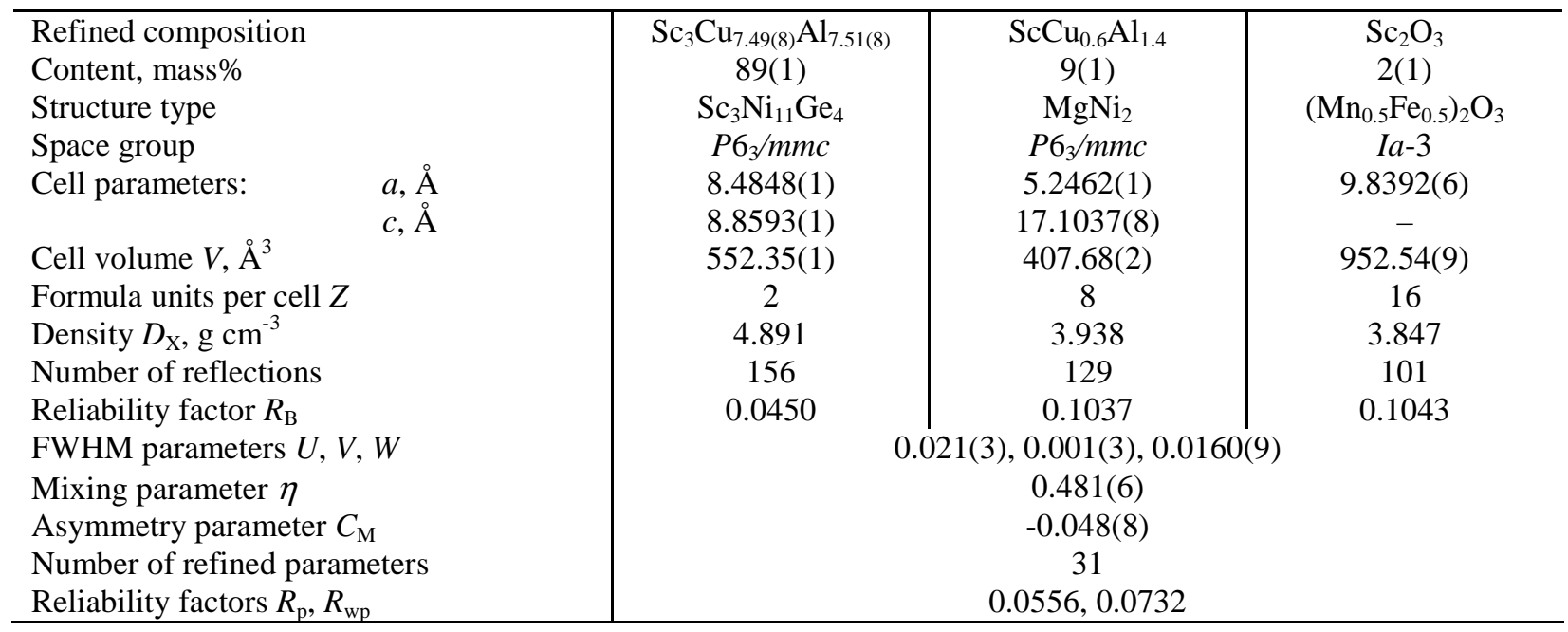


The hexagonal unit cell of $\mathrm{Sc}_{3} \mathrm{Cu}_{7.5} \mathrm{Al}_{7.5}$ contains 36 atoms distributed over seven sites: one site is occupied by Sc atoms, two (partly occupied) by $\mathrm{Cu}$ atoms, and four sites by statistical mixtures of $\mathrm{Cu}$ and $\mathrm{Al}$ atoms in different ratios; the refined composition of the compound was $\mathrm{Sc}_{3} \mathrm{Cu}_{7.49(8)} \mathrm{Al}_{7.51(8)}$. The two $\mathrm{Cu}$ sites $(2 b$ and $2 a$ ) cannot be occupied simultaneously, since too short distances $(2.215 \AA)$ will occur in the structure. The $\mathrm{Sc}$ atoms center $M_{8} \mathrm{Sc}_{2}$ pentagonal prisms with seven $\left(M_{6} \mathrm{Cu}\right)$ additional atoms, whereas the $\mathrm{Cu}$ atoms are situated inside $M_{6}$ trigonal prisms with three $\left(\mathrm{Sc}_{3}\right)$ additional atoms, or $M_{6}$ trigonal antiprisms. The coordination polyhedra of the sites occupied by the atoms of the statistical mixtures are icosahedra: $M_{8} \mathrm{CuSc}_{3}$ for $M 1, M_{10} \mathrm{Sc}_{2}$ for $M 2, M_{8} \mathrm{Sc}_{4}$ for $M 3$, and $M_{9} \mathrm{Sc}_{3}$ for $M 4$.

The structure of $\mathrm{Sc}_{3} \mathrm{Cu}_{7.5} \mathrm{Al}_{7.5}$ is closely related to the structure types $\mathrm{Sc}_{3} \mathrm{Ni}_{11} \mathrm{Ge}_{4} \quad\left(h P 38, P 6_{3} / m m c\right.$, $a=8.130, c=8.505 \AA[15])$ and $\mathrm{Gd}_{3} \mathrm{Ru}_{4} \mathrm{Al}_{12}$ (hP38, $P 6_{3} / m m c, a=8.8142, c=9.5692 \AA$ [16]). As can be seen from Table 5 the structure of $\mathrm{Gd}_{3} \mathrm{Ru}_{4} \mathrm{Al}_{12}$ [17] may be considered as a substitution variant of the structure of $\mathrm{Sc}_{3} \mathrm{Ni}_{11} \mathrm{Ge}_{4}$, which is a partly disordered variant of the $\mathrm{Sc}_{3} \mathrm{Ni}_{11} \mathrm{Si}_{4}$ [18] type, all three structures being ternary derivatives of the binary $\operatorname{ErZn}_{5}[19]$ and $\mathrm{EuMg}_{5.2}[20]$ types.

Table 3 Atom coordinates and isotropic displacement parameters for $\mathrm{Sc}_{3} \mathrm{Cu}_{7.5} \mathrm{Al}_{7.5}$ : structure type $\mathrm{Sc}_{3} \mathrm{Ni}_{11} \mathrm{Ge}_{4}, h P 38, P 6_{3} / m m c, a=8.4848(1), c=8.8593(1) \AA$.

\begin{tabular}{c|c|c|c|c|c}
\hline Site & $\begin{array}{c}\text { Wyckoff } \\
\text { position }\end{array}$ & $x$ & $y$ & $z$ & $B_{\text {iso }}, \AA^{2}$ \\
\hline $\mathrm{Sc}$ & $6 h$ & $0.1980(2)$ & $0.3960(2)$ & $1 / 4$ & $1.19(6)$ \\
$M 1=0.446(6) \mathrm{Cu}+0.554(6) \mathrm{Al}$ & $12 k$ & $0.1563(2)$ & $0.3126(2)$ & $0.5900(2)$ & \\
$M 2=0.443(5) \mathrm{Cu}+0.557(5) \mathrm{Al}$ & $6 h$ & $0.5665(2)$ & $0.1330(2)$ & $1 / 4$ & $1.04(2)$ \\
$M 3=0.738(7) \mathrm{Cu}+0.262(7) \mathrm{Al}$ & $6 g$ & $1 / 2$ & 0 & 0 & \\
$M 4=0.136(6) \mathrm{Cu}+0.864(6) \mathrm{Al}$ & $4 f$ & $1 / 3$ & $2 / 3$ & $0.0026(4)$ & \\
$\mathrm{Cu} 1=0.612(3) \mathrm{Cu}$ & $2 b$ & 0 & 0 & $1 / 4$ & $1.58(9)$ \\
$\mathrm{Cu} 2=0.388(3) \mathrm{Cu}$ & $2 a$ & 0 & 0 & 0 & 0 \\
\hline
\end{tabular}

Table 4 Interatomic distances, coordination numbers $(\mathrm{CN})$, and coordination polyhedra for $\mathrm{Sc}_{3} \mathrm{Cu}_{7.5} \mathrm{Al}_{7.5}$.

\begin{tabular}{|c|c|c|c|c|c|c|c|c|c|}
\hline \multicolumn{2}{|r|}{ Atoms } & $\delta, \AA$ & $\mathrm{CN}$ & Polyhedron & \multicolumn{2}{|c|}{ Atoms } & \multirow[b]{2}{*}{\begin{tabular}{|r|}
$\delta, \AA$ \\
$2.421(1)$ \\
$2.449(0)$ \\
$2.652(1)$ \\
$3.160(1)$
\end{tabular}} & \multirow{2}{*}{\begin{tabular}{|r|}
$\mathrm{CN}$ \\
12
\end{tabular}} & \multirow[t]{2}{*}{ Polyhedron } \\
\hline $\mathrm{Sc}$ & $\begin{array}{l}-1 \mathrm{Cu}^{\mathrm{a}} \\
-2 M 4 \\
-2 M 2 \\
-6 M 1 \\
-4 M 3 \\
-2 \mathrm{Sc}\end{array}$ & $\begin{array}{l}2.909(1) \\
2.960(3) \\
2.979(3) \\
3.011(2) \\
3.160(1) \\
3.446(2)\end{array}$ & 17 & & M3 & $\begin{array}{l}-2 M 2 \\
-2 M 4 \\
-4 M 1 \\
-4 \mathrm{Sc}\end{array}$ & & & \\
\hline$M 1$ & $\begin{array}{ll}-1 & C u 2^{\mathrm{a}} \\
-2 & M 3 \\
-2 & M 2 \\
-1 & C u 1^{\mathrm{a}} \\
-1 & M 4 \\
-3 & M 1 \\
-3 & \mathrm{Sc}\end{array}$ & \begin{tabular}{|l}
$2.431(1)$ \\
$2.652(1)$ \\
$2.668(2)$ \\
$2.698(2)$ \\
$2.729(2)$ \\
$2.796(2)$ \\
$3.011(2)$
\end{tabular} & 12 & & $M 4$ & 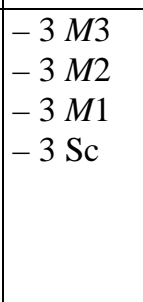 & $\begin{array}{l}2.449(0) \\
2.679(3) \\
2.729(2) \\
2.960(3)\end{array}$ & 12 & \\
\hline$M 2$ & 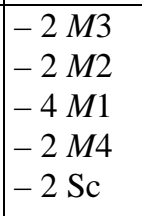 & $\begin{array}{l}2.421(1) \\
2.551(2) \\
2.668(2) \\
2.679(3) \\
2.979(3)\end{array}$ & 12 & & $\mathrm{Cu} 1^{\mathrm{a}}$ & $\begin{array}{l}-2 \mathrm{Cu} 2^{\mathrm{a}} \\
-6 M 1 \\
-3 \mathrm{Sc}\end{array}$ & $\begin{array}{l}2.215(0) \\
2.698(2) \\
2.909(1)\end{array}$ & 9 & \\
\hline & & & & & $\mathrm{Cu} 2^{\mathrm{a}}$ & $\begin{array}{l}-2 \mathrm{Cu}^{\mathrm{a}} \\
-6 M 1\end{array}$ & $\begin{array}{l}2.215(0) \\
2.431(1)\end{array}$ & 6 & \\
\hline & $\begin{array}{l}y \text { occupie } \\
0.388(3)\end{array}$ & ites (Cu1 & & & & & & & \\
\hline
\end{tabular}


Contrary to the structure type $\mathrm{Gd}_{3} \mathrm{Ru}_{4} \mathrm{Al}_{12}$, where an ordered arrangement of alternating $\mathrm{Ru}(2 a)$ and $\mathrm{Al}$ ( $2 b$ ) atoms is observed along the $6_{3}$ axis, but similarly to the type $\mathrm{Sc}_{3} \mathrm{Ni}_{11} \mathrm{Ge}_{4}$, in $\mathrm{Sc}_{3} \mathrm{Cu}_{7.5} \mathrm{Al}_{7.5}$ the Wyckoff sites $2 a$ and $2 b$ are partly occupied. Thus, the structure of the compound $\mathrm{Sc}_{3} \mathrm{Cu}_{7.5} \mathrm{Al}_{7.5}$ may be considered as a partly disordered derivative of the structure type $\mathrm{Sc}_{3} \mathrm{Ni}_{11} \mathrm{Ge}_{4}$. In the structure of $\mathrm{Sc}_{3} \mathrm{Ni}_{11} \mathrm{Ge}_{4}$ each atom site is occupied by one chemical element. However, in the structure of $\mathrm{Sc}_{3} \mathrm{Cu}_{7.5} \mathrm{Al}_{7.5}$ four of the six sites of the smaller atoms are occupied by statistical mixtures of $\mathrm{Cu}$ and $\mathrm{Al}$ atoms, the remaining $\mathrm{Cu}$ atoms being distributed over two sites situated on the $c$-axis, which are partly occupied by $\mathrm{Ge}$ atoms in the prototype.

The structure type $\mathrm{Sc}_{3} \mathrm{Ni}_{11} \mathrm{Ge}_{4}$ has only two known representatives; in addition to the type-defining compound it has been reported for $\mathrm{Yb}_{3} \mathrm{Ni}_{11} \mathrm{Ge}_{4}$ [21]. On the contrary, a relatively large number of representatives are known for the structure type $\mathrm{Gd}_{3} \mathrm{Ru}_{4} \mathrm{Al}_{12}$ [22,23], among which the majority have been reported at the stoichiometric composition $3: 4: 12$. In the case of the compounds $\mathrm{Y}_{3} \mathrm{Ru}_{4} \mathrm{Al}_{12}$ (refined composition $\mathrm{Y}_{3} \mathrm{Ru}_{4.06} \mathrm{Al}_{11.94}$ ) [24] and $\mathrm{U}_{3} \mathrm{Co}_{4} \mathrm{Al}_{12} \quad\left(\mathrm{U}_{3} \mathrm{Co}_{4.55} \mathrm{Al}_{11.45}\right)$ [25] (similarly to the prototype) substitution of $\mathrm{Ru} / \mathrm{Co}$ for $\mathrm{Al}$ takes place on one site, the site in Wyckoff position $6 h$. Refinements of Os-rich compositions of the phases $R_{3} \mathrm{Os}_{4} \mathrm{Al}_{12}$ $(R=\mathrm{Nd}, \mathrm{Gd})$ [24], confirmed preferential substitution on the site in Wyckoff position $6 h$, but very small amounts were also detected in $12 k$ and $4 f$. For the isotypic compound $\mathrm{La}_{3} \mathrm{Ag}_{4} \mathrm{Mg}_{12}$ a different atom distribution was observed [26] at the "ideal" composition. As in the title compound, the minority atoms, in this case $\mathrm{Ag}$, exclusively occupy the site $2 a$. The site $6 g$, which is also occupied by minority atoms in $\mathrm{Gd}_{3} \mathrm{Ru}_{4} \mathrm{Al}_{12}$, contains the major part of the remaining $\mathrm{Ag}$ atoms, but statistical $\mathrm{Ag} / \mathrm{Mg}$ occupations were refined for three sites: $12 k, 6 h, 6 g$. Mixed occupation on all the sites occupied by the smaller atoms ( $\mathrm{Mg}$ and $\mathrm{Ag}$ ), except the site in $2 a$, was refined for $\mathrm{Ce}_{3} \mathrm{Ag}_{4.7} \mathrm{Mg}_{11.3}$ [27], but the refinement clearly showed preferential occupation of site $6 g$ by $\mathrm{Ag}$ atoms. Ordered structures were observed for the isotypic silicides $R_{3} \mathrm{Ni}_{12} \mathrm{Si}_{4}(R=\mathrm{Ho}, \mathrm{Er}, \mathrm{Tm})$ [28], where the positions of the $p$ - and $d$-elements are interchanged with respect to the structure of $\mathrm{Gd}_{3} \mathrm{Ru}_{4} \mathrm{Al}_{12}$. Contrary to the structure reported for $\mathrm{ScNi}_{11} \mathrm{Si}_{4}$, both sites located on the $c$-axis, $2 a$ and $2 b$, were found to be fully occupied.

The structure of $\mathrm{Sc}_{3} \mathrm{Cu}_{7.5} \mathrm{Al}_{7.5}$, similarly to $\mathrm{Sc}_{3} \mathrm{Ni}_{11} \mathrm{Ge}_{4}$ and $\mathrm{Gd}_{3} \mathrm{Ru}_{4} \mathrm{Al}_{12}$, is built up of two kinds of layer perpendicular to the crystallographic direction [001]: planar layers of composition $\mathrm{Sc}_{3} M_{3} \mathrm{Cu}_{0.61}$ and puckered layers of composition $M_{11} \mathrm{Cu}_{0.39}$. As can be seen from Fig. 2, four layers are stacked within the unit cell in the following sequence: $M_{11} \mathrm{Cu}_{0.39^{-}}$ $\mathrm{Sc}_{3} M_{3} \mathrm{Cu}_{0.61}-M_{11} \mathrm{Cu}_{0.39}-\mathrm{Sc}_{3} M_{3} \mathrm{Cu}_{0.61}$.

In the $\mathrm{Sc}_{3} M_{3} \mathrm{Cu}_{0.61}$ layers the $\mathrm{Sc}$ atoms and atoms of the statistical mixture $M 2 \quad(0.443(5) \mathrm{Cu}+$ $0.557(5) \mathrm{Al}$ ) form $\mathrm{Sc}_{3}$ and $M_{3}$ triangles, respectively, which have the same orientation within the layer. The interatomic distances within the triangles are $\delta_{\mathrm{Sc}-\mathrm{Sc}}=3.446(2)$ and $\delta_{M 2-M 2}=2.551(2) \AA$, i.e. the Sc-Sc distances are comparable with the contact distances in pure scandium (3.253 $\AA$ [29]). Hence, one of the main features of the structure is the clustering of the Sc atoms into triangles. The $M_{11} \mathrm{Cu}_{0.39}$ layer is close-packed, however slightly puckered (1.595 ^thick). The layers of the atoms of the statistical mixture $M 1 \quad(0.446(6) \mathrm{Cu}+0.554(6) \mathrm{Al})$ are not situated exactly at the center of the slab, but slightly shifted up and down with respect to the central layer. The latter is composed of atoms of the statistical mixture $M 3(0.738(7) \mathrm{Cu}+0.262(7) \mathrm{Al})$, which form kagome nets, the triangles of which are centered by atoms of the statistical mixture $M 4(0.136(6) \mathrm{Cu}+$ $0.864(6) \mathrm{Al})$. The $\mathrm{Cu}$ atoms from the Wyckoff sites $2 a$ and $2 b$ are located along the crystallographic direction [001] in statistical disorder $(61.2 \%$ at $z=1 / 4$ and $3 / 4$, $38.8 \%$ at $z=0$ and $1 / 2$ ).

Comparing our results with the literature data on the $\mathrm{Sc}-\mathrm{Cu}-\mathrm{Al}$ system, it is interesting to note (see Table 1) that the orthorhombic cell reported for $\mathrm{ScCu}_{2} \mathrm{Al}_{2}$ (compound $\mathrm{A}$ in [2]) is practically identical to the orthohexagonal cell calculated for $\mathrm{Sc}_{3} \mathrm{Cu}_{7.5} \mathrm{Al}_{7.5}$ $\left(a_{\mathrm{o}}=8.46 \approx a_{\mathrm{h}}=8.4848, b_{\mathrm{o}}=8.86 \approx c_{\mathrm{h}}=8.8593\right.$, $c_{\mathrm{o}}=14.65 \approx \sqrt{3} a_{\mathrm{h}}=14.696 \AA$. The hexagonal cell parameters determined for the phase called

Table 5 Distribution of the atoms in different Wyckoff positions of space group $P 6_{3} / m m c$ and site occupations for compounds with related structure types.

\begin{tabular}{c|c|c|c|c|c|c|c}
\hline \multirow{2}{*}{$\begin{array}{c}\text { Wyckoff } \\
\text { position }\end{array}$} & \multicolumn{7}{|c}{ Compound } \\
\cline { 2 - 8 } & $\mathrm{Gd}_{3} \mathrm{Ru}_{4} \mathrm{Al}_{12}$ & $\mathrm{Ce}_{4.7} \mathrm{Ag}_{4.7} \mathrm{Mg}_{11.3}$ & $\mathrm{Sc}_{3} \mathrm{Ni}_{11} \mathrm{Si}_{4}$ & $\mathrm{Sc}_{3} \mathrm{Ni}_{11} \mathrm{Ge}_{4}$ & $\mathrm{Sc}_{3} \mathrm{Cu}_{7.5} \mathrm{Al}_{7.5}$ & $\mathrm{ErZn}_{5}$ & $\mathrm{EuMg}_{5.2}$ \\
\hline $6 h$ & $\mathrm{Gd}$ & $\mathrm{Ce}$ & $\mathrm{Sc}$ & $\mathrm{Sc}$ & $\mathrm{Sc}$ & $\mathrm{Er}$ & $\mathrm{Eu}$ \\
$12 k$ & $\mathrm{Al}$ & $\mathrm{Mg}_{0.94} \mathrm{Ag}_{0.06}$ & $\mathrm{Ni}$ & $\mathrm{Ni}$ & $\mathrm{Al}_{0.554} \mathrm{Cu}_{0.446}$ & $\mathrm{Zn}$ & $\mathrm{Mg}$ \\
$6 h$ & $\mathrm{Al}_{0.96} \mathrm{Ru}_{0.04}$ & $\mathrm{Mg}_{0.89} \mathrm{Ag}_{0.12}$ & $\mathrm{Ni}$ & $\mathrm{Ni}$ & $\mathrm{Al}_{0.557} \mathrm{Cu}_{0.443}$ & $\mathrm{Zn}$ & $\mathrm{Mg}$ \\
$6 g$ & $\mathrm{Ru}$ & $\mathrm{Ag}_{0.97} \mathrm{Mg}_{0.03}$ & $\mathrm{Si}$ & $\mathrm{Ge}$ & $\mathrm{Cu}_{0.738} \mathrm{Al}_{0.262}$ & $\mathrm{Zn}$ & $\mathrm{Mg}$ \\
$4 f$ & $\mathrm{Al}$ & $\mathrm{Mg}_{0.95} \mathrm{Ag}_{0.05}$ & $\mathrm{Ni}$ & $\mathrm{Ni}$ & $\mathrm{Al}_{0.864} \mathrm{Cu}_{0.136}$ & $\mathrm{Zn}$ & $\mathrm{Mg}$ \\
$4 e$ & - & - & - & - & - & $\mathrm{Mg}_{0.26}$ \\
$2 b$ & $\mathrm{Al}$ & $\mathrm{Mg}_{0.95} \mathrm{Ag}_{0.05}$ & $\mathrm{Si}$ & $\mathrm{Ge}_{0.72}$ & $\mathrm{Cu}_{0.612}$ & - & $\mathrm{Mg}_{0.77}$ \\
$2 a$ & $\mathrm{Ru}$ & $\mathrm{Ag}$ & - & $\mathrm{Ge}_{0.28}$ & $\mathrm{Cu}_{0.388}$ & $\mathrm{Zn}$ & $\mathrm{Mg}_{0.40}$ \\
\hline
\end{tabular}




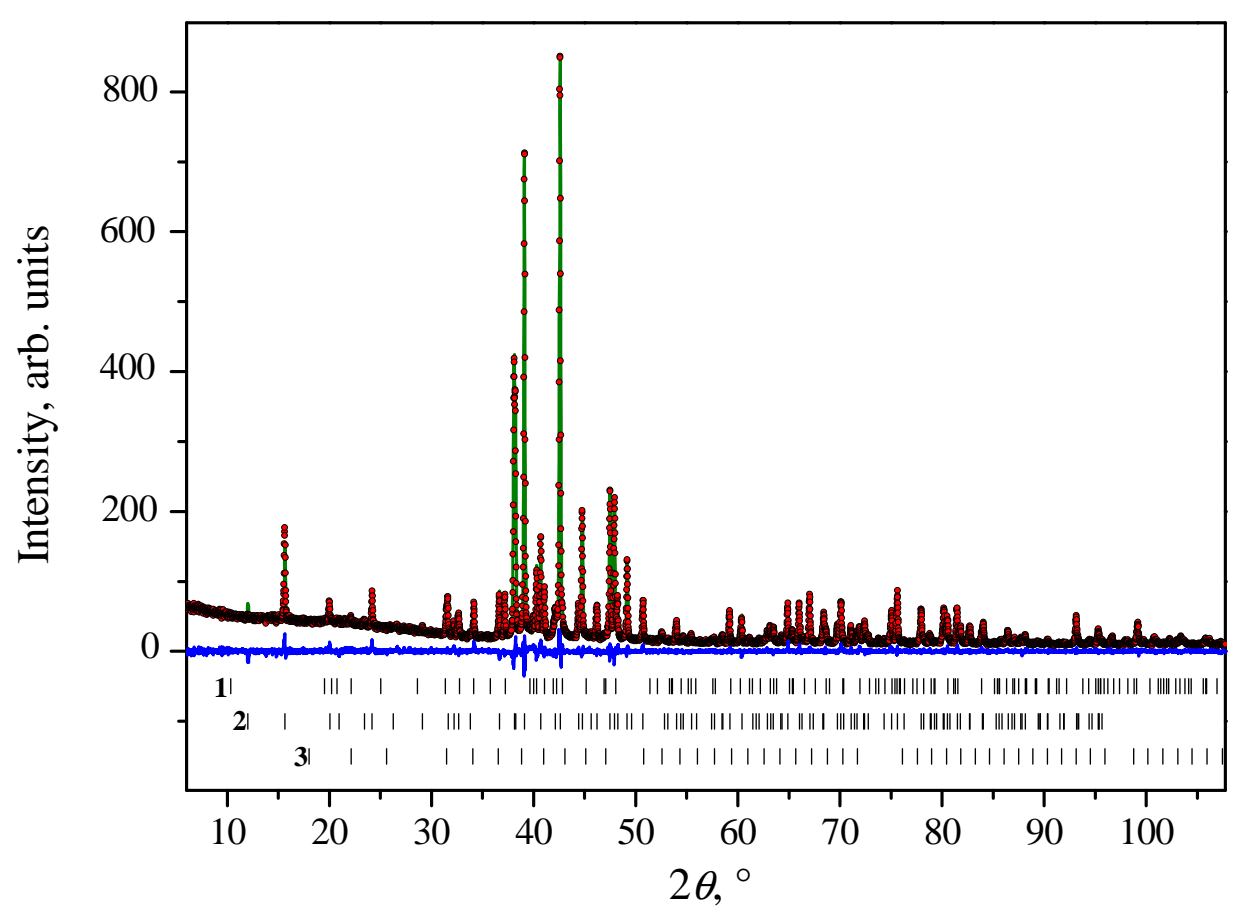

Fig. 1 Experimental (points), calculated (continuous line) and difference (continuous line at the bottom of the picture) X-ray powder diffraction patterns $\left(\mathrm{Cu} K \alpha_{1}\right.$-radiation) of the sample of composition $\mathrm{Sc}_{20} \mathrm{Cu}_{40} \mathrm{Al}_{40}$. Vertical lines show the positions of the reflections of the compounds $\mathrm{Sc}_{3} \mathrm{Cu}_{7.5} \mathrm{Al}_{7.5}$ (1), $\mathrm{ScCu}_{0.6} \mathrm{Al}_{1.4}$ (2), and $\mathrm{Sc}_{2} \mathrm{O}_{3}(3)$.

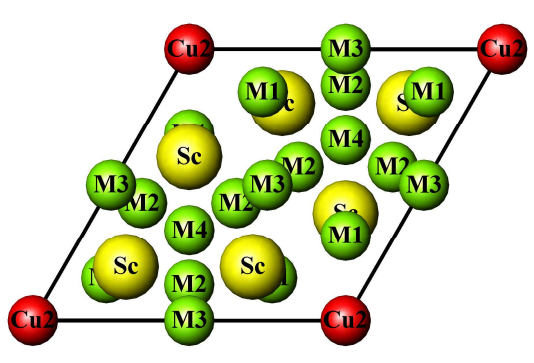

$a$

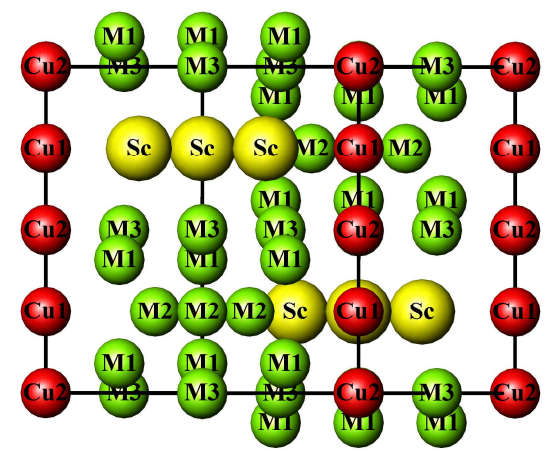

$b$

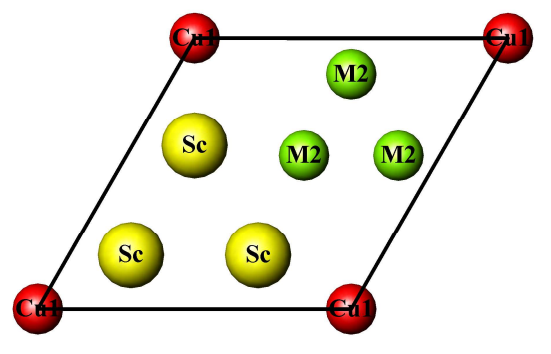

$z=3 / 4$

$c$

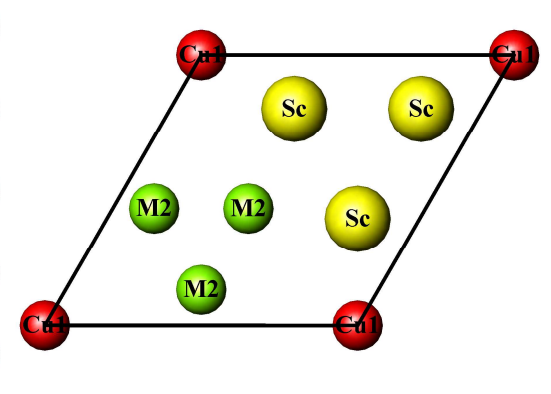

$z=1 / 4$

$d$

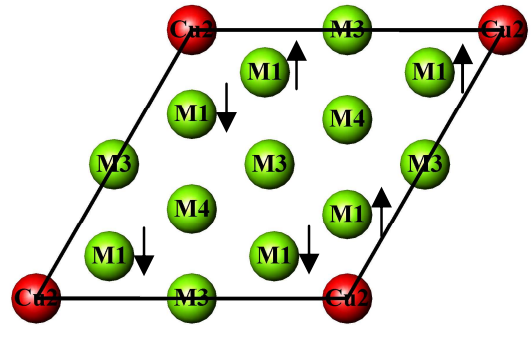

$z \approx 1 / 2$

$e$

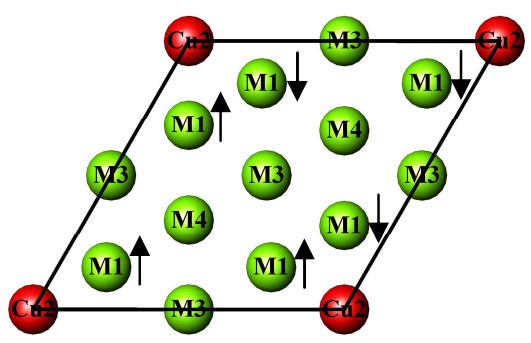

$z \approx 0$

$f$

Fig. 2 Projection of the unit cell of the structure of the compound $\mathrm{Sc}_{3} \mathrm{Cu}_{7.5} \mathrm{Al}_{7.5}$ along the crystallographic direction [001] (a), stacking of layers along [001] $(b)$ and the $\mathrm{Sc}_{3} M_{3} \mathrm{Cu}_{0.61}(c, d)$ and $M_{11} \mathrm{Cu}_{0.39}(e, f)$ layers. Arrows indicate shifts of the atoms up and down with respect to the central layer. 
$\mathrm{Sc}_{6} \mathrm{Cu}_{16.4} \mathrm{Al}_{13.9}$ [8] are also very close to the values refined here, however this phase was assumed to correspond to the earlier reported $\sim \mathrm{ScCu}_{3} \mathrm{Al}_{2}(\mathrm{C}$ in [2]). It is not excluded that the $\mathrm{Sc}_{3} \mathrm{Cu}_{7.5} \mathrm{Al}_{7.5}$ phase has a certain homogeneity range extending along the isoconcentrate 16.7 at.\% Sc.

\section{Conclusions}

The ternary compound of refined composition $\mathrm{Sc}_{3} \mathrm{Cu}_{7.49(8)} \mathrm{Al}_{7.51(8)}$ crystallizes with a structure that is closely related to the structure types $\mathrm{Sc}_{3} \mathrm{Ni}_{11} \mathrm{Ge}_{4}$ and $\mathrm{Gd}_{3} \mathrm{Ru}_{4} \mathrm{Al}_{12}$. The hexagonal unit cell of $\mathrm{Sc}_{3} \mathrm{Cu}_{7.5} \mathrm{Al}_{7.5}$ contains 36 atoms distributed over seven sites. The Sc atoms center pentagonal prisms with seven additional atoms, and the $\mathrm{Cu}$ atoms are situated inside trigonal prisms or antiprisms. The coordination polyhedra of the sites occupied by atoms of the statistical mixtures of $\mathrm{Cu}$ and $\mathrm{Al}$ atoms are icosahedra. The main feature of the structure is the clustering of the $\mathrm{Sc}$ (the minority element) atoms.

\section{Acknowledgements}

The authors are grateful to Dr K. Cenzual for her critical comments during the careful reading of the manuscript. This work was carried out under the grant of the Ministry of Education and Science of Ukraine No. 0115U003257 and under the project "Search for new structure types" of the company Material Phases Data System (Vitznau, Switzerland).

\section{References}

[1] P. Riani, L. Arrighi, R. Marazza, D. Mazzone, G. Zanicchi, R. Ferro, J. Phase Equilib. Diff. 25 (2004) 22-52.

[2] A.P. Prevarskii, O.S. Zarechnyuk, E.E. Cherkashin, V.I. Policha, Visn. Lviv. Derzh. Univ., Ser. Khim. 18 (1976) 14-16.

[3] M.Y. Teslyuk, V.S. Protasov, Sov. Phys. Crystallogr. 10 (1966) 470-471.

[4] M.L. Kharakterova, T.V. Dobatkina, Russ. Metall. (6) (1988) 175-178.

[5] M.L. Kharakterova, Russ. Metall. (4) (1991) 195-199.

[6] L.S. Toropova, M.L. Kharakterova, D.G. Eskin, Russ. Metall. (3) (1992) 194-199.

[7] E.I. Gladyshevskii, Z.M. Shpyrka, M.B. Konyk, Coll. Abstr. 6th Symp. Cryst. Chem. Inorg. Coord. Compd., Lviv, 1992, 170.

[8] N.Z. Nakonechna, Z.M. Shpyrka, M.B. Konyk, E.I. Gladyshevskii, Coll. Abstr. 6th Int. Conf. Cryst. Chem. Intermet. Compd., Lviv, 1995, 40.

[9] N.Z. Nakonechna, Z.M. Shpyrka, Visn. Lviv. Derzh. Univ., Ser. Khim. 36 (1996) 29-33.
[10] A.E. Dwight, C.W. Kimball, J. Less-Common Met. 127 (1987) 179-182.

[11] T. Ishimasa, A. Hirao, T. Honma, M. Mihalkovic, Philos. Mag. 91 (2011) 2594-2602.

[12] N. Klymentiy, N. Semuso, S. Pukas, Ya. Tokaychuk, L. Akselrud, R. Gladyshevskii, Solid State Phenom. (in press).

[13] R.A. Young, A. Sakthivel, T.S. Moss, C.O. Paiva-Santos, J. Appl. Crystallogr. 28 (1995) 366-367.

[14] E. Dowty, ATOMS, A Computer Program for Displaying Atomic Structures, Kingsport, TN, USA, 1999.

[15] R.I. Andrusyak, Sov. Phys. Crystallogr. 33 (1988) 599-600.

[16] R.E. Gladyshevskii, O.R. Strusievicz, K. Cenzual, E. Parthé, Acta Crystallogr. B 49 (1993) 474-478.

[17] E. Parthé, L. Gelato, B. Chabot, M. Penzo, K. Cenzual, R. Gladyshevskii, TYPIX Standardized Data and Crystal Chemical Characterization of Inorganic Structure Types, Gmelin Handbook of Inorganic and Organometallic Chemistry, Springer-Verlag, Berlin, 1993/1994, Vols. 1-4, 1596 p.

[18] B.Y. Kotur, M. Sikiritsa, O.I. Bodak, E.I. Gladyshevskii, Kristallografiya 28 (1983) 658-661.

[19] M.L. Fornasini, J. Less-Common Met. 25 (1971) 329-332.

[20] J. Erassme, H. Lueken, Acta Crystallogr. B 43 (1987) 244-250.

[21] R.B. Dzyanyi, O.I. Bodak, V.V. Pavlyuk, Russ. Metall. (4) (1995) 133-135.

[22] P. Villars, K. Cenzual (Eds.), Pearson's Crystal Data, Crystal Structure Database for Inorganic Compounds, ASM, Materials Park, Ohio, 2016/17.

[23] P. Villars, K. Cenzual, R. Gladyshevskii, Handbook of Inorganic Substances 2016, Walter de Gruyter, Berlin, 2016, 1877 p.

[24] W. Jeitschko, J. Niermann, Z. Anorg. Allg. Chem. 628 (2002) 2549-2556.

[25] R. Troc, H. Noël, O. Tougait, J. Solid State Chem. 177 (2004) 2053-2057.

[26] A. Saccone, V.V. Pavlyuk, P.G. Solokha, S. De Negri, Intermetallics 19 (2011) 671-681.

[27] Y. Verbovytskyy, A.P. Gonçalves, Solid State Sci. 40 (2015) 84-91.

[28] F. Yuan, Y.A. Mozharivskyj, A.V. Morozkin, A.V. Knotko, V.O. Yapaskurt, M. Pani, A. Provino, P. Manfrinetti, J. Solid State Chem. 219 (2014) 247-258.

[29] D.R. Kammler, M.A. Rodriguez, R.G. Tissot, D.W. Brown, B. Clausen, T.A. Sisneros, Metall. Mater. Trans. A 39 (2008) 2815-2819. 